\title{
COMPARISON OF EARLY AND DELAYED LAPAROSCOPIC CHOLECYSTECTOMY FOR ACUTE CHOLECYSTITIS: EXPERIENCE FROM TWO CENTERS IN BASRAH
}

\author{
Habeeb Flayyih Hussein ${ }^{@}$, Rafid Abduljabbar Mohammed ${ }^{\$}$, Mushtaq \\ C Abu-Al-Hail ${ }^{\#}$, \& Omran S Habib\% \\ ${ }^{\circledR} \mathrm{MB}, \mathrm{ChB}, \mathrm{CABS}$, General and Laparoscopic Surgeon, Alsadr Teaching Hospital. ${ }^{\$} \mathrm{MB}, \mathrm{ChB}, \mathrm{CABS}$, \\ MRCS, General Surgeon and Lecturer at Basrah College of Medicine. ${ }^{\# M B}, \mathrm{ChB}$, CABS, Consultant \\ General and Laparoscopic Surgeon, Basrah Teaching Hospital. ${ }^{\%} \mathrm{PhD}$, Professor of Epidemiology and \\ Health Care, Department of Community Medicine, Basrah College of Medicine, Basrah, IRAQ.
}

\begin{abstract}
Calculous cholecystitis is a major and common health problem, and nowadays laparoscopic cholecystectomy is the preferred approach for its surgical management but timing of surgery is a matter of debate especially in presence of acute inflammation of the gall bladder.

The aim of this study is to compare the outcome of early and delayed laparoscopic cholecystectomy for acute cholecystitis.

This retrospective comparative study was done in two tertiary hospitals in Basrah from July 2010 to July 2017. It involved 122 cases (98 females 80.3\% and 24 males $19.7 \%$ ). Forty two (34.5\%) underwent early laparoscopic cholecystectomy within 4 days of symptoms and 80 patients $(65.5 \%)$ underwent delayed operation within $6-12$ weeks of first presentation.

The two groups were comparable in regard to demographic and clinical points of view. The age of studied patients lies between 20-65 years. The operative time was not identical for the two groups $(\mathrm{P}=0.004)$, early treated cases tended to take longer operative time. Hospital stay was significantly longer in early cases as compared to delayed cases $(\mathrm{p}=0.000)$. Bile leak happened in only one case $(2.4 \%)$ of the early group and was managed successfully and discharged well. Bleeding and respiratory infection were extremely rare in both groups. Conversion rate was $4.8 \%$ and $5 \%$ for the early and delayed group respectively and the difference was statistically not significant ( $p$ value 0.661 ).

In conclusion, early laparoscopic cholecystectomy in acute cholecystitis is safe and feasible in selected patients with no difference in morbidity and mortality if it done during the $1^{\text {st }}$ four days of beginning of symptoms, but the operative time is longer than delayed operation.
\end{abstract}

\section{Introduction}

Cholelithiasis is a common have existed throughout the human history and it was discovered in Egyptian mummies ${ }^{1}$. In developed countries, gall stones affect $10-15 \%$ of the adult population $^{2}$. Acute cholecystitis is a major health problem, it is the complication that comprises $20 \%$ of gall bladder disease ${ }^{3}$.

In 1882 Carl Langenbuch performed the first open cholecystectomy and in 1985, 
Dr Erich Mühe performed the first laparoscopic cholecystectomy ${ }^{4}$.

Laparoscopic Cholecystectomy is commonly performed after resolution of the acute inflammation (the conservative initial management approach), this is the favorable approach by the general surgeons due to the fear of operative complications and difficulty of dissection at Calot triangle. Although it is the commonest laparoscopic procedure, timing of surgery is still controversial ${ }^{5}$.

Recently, with increasing experience and improvement instrumentation and the advent of high resolution technology, laparoscopic cholecystectomy became the definitive solution for acute calculous cholecystitis in anesthetically fit patients $^{2,6}$.

Early laparoscopic cholecystectomy appears to be safe, and good results are achieved if the operation was done in first 5-7 days by an expert surgeon with presence of excellent operating facilities ${ }^{7}$. Regarding timing of decision for early laparoscopic cholecystectomy, surgery might be done during the first 10 days of beginning of symptoms, but in patients with more than ten days symptoms, postponing cholecystectomy for six weeks gives better results than early surgery $^{2}$.

Early and delayed laparoscopic cholecystectomy have been defined differently by different randomized controlled trials. In the old literature there is no debate about favorability of delayed cholecystectomy but recently there are changing trends in the treatment of acute cholecystitis. Surgery is perceived as a decision that is better than observation ${ }^{2}$.

Tokyo guidelines recommended that early operation should be done if the Charlson comorbidity index $(\mathrm{CCI}) \leq 5$ and American Society of Anesthesiologists physical status (ASAPS) score $\leq 2$ (ie Early laparoscopic cholecystectomy is the first-line treatment for cases of Grade I $)^{8}$. This study aimed at comparing the outcome of early and delayed laparoscopic cholecystectomy for acute cholecystitis.

\section{Patients and Methods}

This is a retrospective and comparative study, conducted at the surgical units of two tertiary hospitals in Basrah-Iraq, (AlSadr Teaching Hospital and Basrah Teaching Hospital) from July 2010 to July 2017.

The study involved revision of files of 122 cases of acute calculous cholecystitis (42 patients underwent early laparoscopic cholecystectomy and 80 patients underwent delayed operation). On admission, a detailed history was taken, general physical and systemic examination and laboratory investigations were done for all the patients, besides chest x-rays, electrocardiogram, and abdominal ultrasound.

Patients who were excluded from the study were those with obstructive jaundice (direct hyperbilrubinemia), patients with CBD stones, malignant disease, acute gallstone pancreatitis, history of upper abdominal operation, a significant severe medical disease, morbidly obese patients, and those who disagreed to undergo laparoscopic surgery.

Acute cholecystitis was diagnosed clinically depending on the finding of acute epigastric pain, associated nausea or vomiting, with tenderness in right hypochondrium, positive Murphy's sign, fever $(>38 \mathrm{c})$, and ultrasonographic findings of acute cholecystitis like gall bladder distension, finding of gallstones with gallbladder wall thickening and edema, and collection of pericholecystic fluid. Total leukocyte count $(>11,000 / \mathrm{mm} 3)$ in these patients was regarded as additional diagnostic criteria for acute cholecystitis.

The patients were admitted with a diagnosis of acute calculous cholecystitis and all patients who were presented within 4 days of admission, agreed to do surgery and fulfilled the inclusion criteria 
were selected to do early laparoscopic cholecystectomy (early group, $\mathrm{n}=42$ ). The second group received conservative management initially followed by delayed interval surgery 6-12 weeks later (delayed group, $\mathrm{n}=80$ ).

The management was the same in the two groups at admission in the acute period. All patients received intravenous fluids and i.v. antibiotics (third generation cephalosporin) and analgesics. For patients belonged to the early group, laparoscopic cholecystectomy was performed within the 4 days limit by general surgeons licensed in laparoscopic surgery. Patients in the delayed group were treated conservatively and discharged as soon as the acute attack subsided, they were readmitted 6-12 weeks later for elective laparoscopic cholecystectomy.

In the operating room, the patients were placed in supine position and administered general anesthesia. Pneumoperitoneum (12-14 $\mathrm{mmHg}$ ) was created by a blind trocar puncture through a subumbilical incision using $10 \mathrm{~mm}$ trocar. Four ports were used: Two 10millimeter (mm) ports and two 5-mm ports. Nasogastric aspiration if needed. After inspection of the gall bladder, liver, duodenum and peritoneal cavity and after freeing of pericholecystic adhesions (if any), dissection starts at Calots triangle, followed by clipping and division of cystic duct and artery, dissection of the gall bladder from the liver bed and finally extraction of the gall bladder. Intraoperatively, the surgeon adopts some modifications when are necessary. These consisted of gallbladder decompression, irrigation and aspiration of Morrisons pouch by normal saline if there was bleeding or bile spillage, widening of the epigastric port for extraction of the gall bladder and insertion of a tube drain in the subhepatic space. Postoperatively, intravenous fluids, parenteral antibiotics, and analgesics were given to the patients as needed. Oral feeding was started as soon as tolerated and i.v. antibiotics were switched to oral antibiotics. The patients were followed by the managing surgeons at both the private and the outpatient clinics for three months after discharge from the hospital. Data were analyzed by the use of the Statistical Package for Social Sciences (SPSS) software version 23 using $\mathrm{X}^{2}$ test or Fisher Exact Test. P value of less than 0.05 was considered as significant.

\section{Results}

A total of 122 patients (98 females $80.3 \%$ and 24 males $19.7 \%$ ) with a diagnosis of acute calculous cholecystitis were included in the study. They were categorized into two groups; early group (42 patients 34.5\%) in whom early surgery was performed within four days of the onset of symptoms, late group (80 patients $65.5 \%$ ) in whom surgery was performed within 6-12 weeks from the onset of symptoms. The two groups were comparable in regard to the age and sex. The age of patients ranged between 20-65 years. Table I summarizes the comparison between cases with early surgery and cases with delayed surgery with respect to three characteristics.; age, gender and number of stones. The two groups are fairly similar to each other with respect to these characteristics $(\mathrm{P}<0.05)$. 
Table I: General characteristics of the studied patients

\begin{tabular}{|c|c|c|c|c|c|}
\hline Characteristic & $\begin{array}{l}\text { Early } \\
\text { Grol } \\
\text { No. }\end{array}$ & $\%$ & $\begin{array}{l}\text { Del } \\
\text { Gro } \\
\text { No. }\end{array}$ & $\begin{array}{c}\text { urgery } \\
\%\end{array}$ & $\begin{array}{l}\mathrm{P} \text { value (Based on } \\
\mathrm{X}^{2} \text { test) }\end{array}$ \\
\hline $\begin{array}{l}\text { Age } \\
<30 \\
30-39 \\
40-49 \\
50+\end{array}$ & $\begin{array}{l}7 \\
8 \\
17 \\
10\end{array}$ & $\begin{array}{l}16.7 \\
19.0 \\
40.5 \\
23.8\end{array}$ & $\begin{array}{l}13 \\
22 \\
27 \\
18\end{array}$ & $\begin{array}{l}16.4 \\
27.5 \\
33.8 \\
22.5\end{array}$ & 0.068 \\
\hline $\begin{array}{l}\text { Gender } \\
\text { Male } \\
\text { Female }\end{array}$ & $\begin{array}{l}7 \\
35\end{array}$ & $\begin{array}{l}16.7 \\
83.3\end{array}$ & $\begin{array}{l}17 \\
63\end{array}$ & $\begin{array}{l}21.3 \\
78.7\end{array}$ & 0.162 \\
\hline $\begin{array}{l}\text { Number of stones } \\
\text { Single } \\
\text { Multiple }\end{array}$ & $\begin{array}{l}8 \\
34 \\
\end{array}$ & $\begin{array}{l}19.0 \\
81.0\end{array}$ & $\begin{array}{l}9 \\
71 \\
\end{array}$ & $\begin{array}{l}11.3 \\
88.7\end{array}$ & 0.107 \\
\hline Total & 42 & 100.0 & 80 & 100.0 & \\
\hline
\end{tabular}

With respect to selected clinical and medical characteristics, the two groups show similarities regarding presence of right hypochondrial lump, level of indirect billirubin, history of hypertension, diabetes mellitus and traits of both thallasemia and sickle cell anemia. However, the two groups were significantly different with respect to presence of tenderness, Murphys sign, Fever $\geq 38 \mathrm{C}, \mathrm{WBC}$ count, wall thickness and ultrasonic detection of pericholecystic fluid $(\mathrm{P}<0.001)$ as shown in table II.

Table II: Selected clinical characteristics(No. \& \% of patients with positive results)

\begin{tabular}{|c|c|c|c|c|c|}
\hline \multirow[t]{2}{*}{ Characteristic } & \multicolumn{2}{|c|}{$\begin{array}{l}\text { Early Surgery } \\
\text { Group }\end{array}$} & \multicolumn{2}{|c|}{$\begin{array}{l}\text { Delayed } \\
\text { Surgery Group }\end{array}$} & \multirow[t]{2}{*}{$\begin{array}{l}\mathrm{P} \text { value based on } \mathrm{X}^{2} \text { test or } \\
\text { Fisher Exact Test }\end{array}$} \\
\hline & No. & $\%$ & & $\%$ & \\
\hline Tenderness & 42 & 100.0 & 35 & 43.8 & 0.000 \\
\hline $\begin{array}{l}\text { Right hypochondrial } \\
\text { lump }\end{array}$ & 10 & 23.8 & 15 & 18.8 & 0.332 \\
\hline Murphys sign & 31 & 73.8 & 15 & 18.8 & 0.000 \\
\hline Fever $\geq 38 \mathrm{C}$ & 39 & 92.9 & 6 & 7.5 & 0.000 \\
\hline $\mathrm{WBCs} \geq 11000 / \mathrm{mm} 3$ & 40 & 95.2 & 19 & 23.8 & 0.000 \\
\hline $\begin{array}{l}\text { Indirect } \\
\text { bilirubinaemia }\end{array}$ & 3 & 7.1 & 3 & 3.8 & 0.339 \\
\hline Wall thickness $\geq 4 \mathrm{~mm}$ & 42 & 100.0 & 59 & 73.8 & 0.000 \\
\hline Pericholecystic fluid & 31 & 73.8 & 9 & 11.3 & 0.000 \\
\hline Hypertension & 8 & 19.0 & 15 & 18.8 & 0.574 \\
\hline Diabetes mellitus & 7 & 16.7 & 9 & 11.3 & 0.283 \\
\hline Thalassemia trait & 2 & 4.8 & 2 & 2.5 & 0.427 \\
\hline Sickle cell trait & 1 & 2.4 & 1 & 1.3 & 0.572 \\
\hline
\end{tabular}

Table III-A, Shows the results related to intra-operative findings and measures by surgeon. Gall bladder aspiration was more frequently resorted to in early operated cases as compared to delayed cases $(\mathrm{P}=0.000)$. The same was true for irrigation and drain use. Epigastric port widening was more frequently needed in delayed cases $(\mathrm{P}=0.000)$. With respect to nasogastric tube deflation, the two groups show similar pattern $(\mathrm{P}=0.138)$. 
The operative time was not identical for the two groups $(\mathrm{P}=0.004)$, early treated cases tended to take longer operative time. Table III-B, shows that hospital stay was significantly longer in early cases as compared to delayed cases $(p=0.000)$. Perforation of gall bladder tended to be more frequent in early treated cases but the difference was statistically not significant $(\mathrm{P}=0.063)$. Regarding other complications like bleeding and respiratory complications, they were extremely rare in both groups. Two important findings but not significantly different in the two groups are development of ileus and conversion to open surgery were shown in the same table.

Table III A\&B: Intra-operative findings \& postoperative sequelae in both groups

\begin{tabular}{|c|c|c|c|c|c|}
\hline \multirow{2}{*}{$\begin{array}{l}\text { Variable } \\
\text { A. Intraoperative findings }\end{array}$} & \multicolumn{2}{|c|}{ Early Surgery Group } & \multicolumn{2}{|c|}{ Delayed Surgery Group } & \multirow{2}{*}{$\begin{array}{l}\mathrm{P} \\
\text { value }\end{array}$} \\
\hline & No. & $\%$ & No. & $\%$ & \\
\hline Gall Bladder Aspiration & 34 & 81.0 & 39 & 48.8 & 0.000 \\
\hline Epigastric Port Widening & 37 & 88.1 & 33 & 41.3 & 0.000 \\
\hline NG Tube deflation & 26 & 61.9 & 46 & 57.5 & 0.138 \\
\hline $\begin{array}{l}\text { Irrigation \& Aspiration of } \\
\text { Morrisons Pouch }\end{array}$ & 38 & 90.5 & 38 & 45.5 & 0.000 \\
\hline Drain use & 42 & 100.0 & 20 & 25.0 & 0.000 \\
\hline $\begin{array}{l}\text { Operative time (minutes) } \\
<45 \\
45-59 \\
60+\end{array}$ & $\begin{array}{l}1 \\
19 \\
22 \\
\end{array}$ & $\begin{array}{c}2.4 \\
45.2 \\
52.4 \\
\end{array}$ & $\begin{array}{l}13 \\
40 \\
27 \\
\end{array}$ & $\begin{array}{l}16.3 \\
50.0 \\
33.8 \\
\end{array}$ & 0.004 \\
\hline $\begin{array}{l}\text { Operative time: } \\
\text { Mean } \pm \text { SD (Minutes) }\end{array}$ & \multicolumn{2}{|c|}{$61.26 \pm 13.18$} & \multicolumn{2}{|c|}{$53.18 \pm 10.83$} & 0.000 \\
\hline \multicolumn{6}{|l|}{$\begin{array}{l}\text { B. Operative \& } \\
\text { Postoperative sequelae }\end{array}$} \\
\hline $\begin{array}{l}\text { Hospital stay } \\
1-2 \text { days } \\
\text { 3-4 days }\end{array}$ & $\begin{array}{l}25 \\
17\end{array}$ & $\begin{array}{l}59.5 \\
40.5\end{array}$ & & $\begin{array}{l}90.0 \\
10.0\end{array}$ & 0.000 \\
\hline $\begin{array}{l}\text { Hospital stay in days } \\
(\text { Mean } \pm \text { SD) }\end{array}$ & \multicolumn{2}{|c|}{$2.50 \pm 0.74$} & \multicolumn{2}{|c|}{$1.46 \pm 0.78$} & 0.000 \\
\hline GB perforation & 11 & 26.2 & 12 & 15.0 & 0.063 \\
\hline Ileus & 3 & 7.1 & 3 & 3.8 & 0.232 \\
\hline Conversion & 2 & 4.8 & 4 & 5.0 & 0.661 \\
\hline Bleeding & 2 & 4.8 & 0 & 0.0 & 0.117 \\
\hline Bile leak & 1 & 2.4 & 0 & 0.0 & 0.344 \\
\hline Bronchitis & 1 & 2.4 & 0 & 0.0 & 0.344 \\
\hline Basal pneumonia & 0 & 0.0 & 0 & 0.0 & $\begin{array}{ll}---- \\
\end{array}$ \\
\hline Atelactasis & 1 & 2.4 & 0 & 0.0 & 0.344 \\
\hline Total & 42 & $\begin{array}{ll}---- \\
\end{array}$ & 80 & ---- & \\
\hline
\end{tabular}

\section{Discussion}

Laparoscopic cholecystectomy had replaced open surgery for gall stone disease and the preferred approach of acute cholecystitis is early rather than delayed one in fit patients ${ }^{6,7}$. This will obviate the consequences of delaying surgery in term of recurrent attacks and absence from work and increase in total 
expenses, on the reverse some studies proved that early surgery is cost effective $^{9-11}$. In this comparative retrospective study, we compared the outcome of management in two groups of patients with acute calculous cholecystitis, early surgery within 4 days and late surgery within 6-12 weeks. The patients who were included in this study from two tertiary centers in Basrah that provide similar management. The two groups had similar demographic criteria.

The optimal timing of early surgery is still a controversial issue, but it is assumed that surgery within the first 72 hours is the best if the surgeon is planning for early laparoscopic cholecystectomy $^{6,12}$. Other studies advocate surgery within seven days ${ }^{13}$. The World Society of Emergency Surgery (WSES) 2016 guidelines on acute calculous cholecystitis declared that early surgery should not be done beyond ten days from the onset of symptoms unless it is complicated by sepsis or peritonitis that necessitates an emergency surgical procedure $^{2}$. Condilis et al found that surgery is faster and easier when performed in first 4-5 days of the onset of symptoms ${ }^{14}$. In a study that was done in Birdem General Hospital in Dhaka, Bangladish, the mean operating time was $68 \mathrm{~min}(35-122 \mathrm{~min})$ for the cases that were operated upon within the first 24 hours of admission ${ }^{15}$. Kolla et al, in a prospective randomized trial, they compared the result of early surgery within 24 hours with delayed surgery within 6-12 weeks, the operating time was $104 \mathrm{~min}$ for the early group and 93 min for the delayed but the difference was statistically not significant ${ }^{16}$. In a prospective comparative study that was carried out in the department of General Surgery Jinnah Postgraduate Medical Centre in Karachi, the mean operative time for cases of acute cholecystitis was 58 minutes compared to 45 minutes for cases of chronic cholecystitis ${ }^{17}$. In this study, early group took a longer operative time $(61.26 \pm 13.18 \mathrm{~min})$ as compared to the delayed group (53.18 $\pm 10.83 \mathrm{~min})$ and the difference was statistically significant $(\mathrm{P}$ value $=0.000)$. This is attributed to the more need for extra steps during surgery (gall bladder decompression, difficulty in grasping edematous friable gall bladder tissue, irrigation and aspiration of Morrisons pouch in case of bile or stone spillage and the liberal use of tube drain. These are additional technical measures that can aid in safe dissection and safe results of the operation.

Different studies showed that early laparoscopic cholecystectomy for acute cholecystitis is safe in expert hands and mild comorbidities but the conversion rate is still high usually due to inflammation, edema and obscuring of Calots triangle and difficult manipulation and traction of the gall bladder. Siddiqui et al in their analysis of four clinical studies discovered shorter hospital stay in early group but they did not found a significant difference in conversion rate ${ }^{18}$. In a retrospective study that was done in National Taiwan University Hospital, Chang TC et al concluded that although early laparoscopic cholecystectomy is safe with a short hospitalization but it is technically demanding and time consuming ${ }^{19}$.

The conversion rate to open surgery is still high, it ranges from $6-35 \%{ }^{3}$ and the conversion rate is $10-15 \%$ higher in patients with acute cholecystitis in comparison with chronic cholecystitis ${ }^{12}$. In our study, the rate of conversion was $4.8 \%$ ( 2 patients) in early group and $5 \%$ (4 patients) for the delayed group, the difference was statistically not significant between the 2 groups. The main cause for conversion in the early group was difficulty in identification of Calots triangle because of the acute inflammation and the second reason for conversion was bleeding. The cause of conversion in the delayed group was fibrosis and adhesions associated with chronic inflammatory process and hence 
difficulty to identify and dissect structures in Calots triangle.

Masayuki et al, found no difference in conversion rate between early laparoscopic cholecystectomy (within 4 days) and delayed group (after 6 weeks) ${ }^{20}$. The same results had been reached by Skouras $\mathrm{C}$ et al in a study in $\mathrm{UK}^{21}$. Different studies showed that there is no difference in morbidity and mortality rate in early laparoscopic cholecystectomy as compared to the elective setting ${ }^{12,22,23}$.

Bile leak and bile duct injuries are troublesome and fatal complications due to sepsis and fluids and electrolyte disturbances. Fatih et al, in a prospective study which had been done in Turkey to assess the outcome of early laparoscopic cholecystectomy found that the incidence of bile duct injury was $1.1 \%{ }^{3}$. In a study done in king Saud Medical City in Riyadh between January 2006 and December 2011, there was no significant increase in bile duct injuries ${ }^{24}$. Bile leak occurred in one patient of the group of early laparoscopic cholecystectomy $(2.4 \%)$, it happened in the fifth postoperative day, the patient was readmitted, treated by placement of percutaneous ultrasound guided tube drain, the amount of bile was less than $200 \mathrm{ml} / 24 \mathrm{~h}$, then the patient was evaluated by MRCP which revealed a retained small CBD stone which was extracted by ERCP with dramatic improvement and the drain was removed five days later.

In our study, bleeding happened in two patients $(5 \%)$ of the early laparoscopy group. Both of them did not require blood transfusion, one of the cases switched to open surgery, the second one was kept on conservative treatment. The difference of frequency of bleeding was not statistically significant between the early and delayed group.

We reported two cases of respiratory complications in the early group, one case of atelectasis and one case of bronchitis, both of them managed successfully and discharged well.

In the study that was done by Chang et al, they found that patients with early laparoscopic cholecystectomy had shorter total hospital stay in comparison with the delayed group (4.5 days versus 7.7 days). The same conclusion of shorter total hospital stay had been reached by another two studies, the first had been done in Saudi Arabia by Al-Mulhim ${ }^{25}$ and the second in India by Prakash et $\mathrm{al}^{26}$. In our study, hospital stay was longer for the early group in comparison with the delayed group (ninety percent of cases of delayed laparoscopic cholecystectomy discharged within the first two days). The reasons for longer hospital stay of the early group were presence of fever and the use of drain. Subhepatic tube drains were used in all cases of the early group and only in $25 \%$ of the delayed group .

To conclude, early laparoscopic cholecystectomy in acute cholecystitis is safe and feasible in selected patients with no difference in morbidity and mortality if it is done within the first four days of onset of symptoms, but the operative time is longer than delayed operation.

\section{References}

1- Cesarani F, Martina M.C, Boano R, Grilletto R,D’Amicone E, Venturi C and Gandini G. Multidetector CT Study of Gallbladder Stones in a Wrapped Egyptian Mummy. RadioGraphics 2009;29:1191-1194 •

2- Ansaloni et al. WSES guidelines on acute calculous cholecystitis. World Journal of Emergency Surgery (2016) 11:25 .

3- Ciftci F., Abdurrahman I., Girgin S.The Outcome of Early Laparoscopic Surgery to Treat Acute Cholecystitis:A Single-Center Experience. Int J Clin Exp Med. 2015; 8(3): 4563-4568.

4- Reynolds W.The First Laparoscopic Cholecystectomy. Journal of the Society of Laparoscopic Surgeons 2001 Jan-Mar; 5(1): 89-94. 
5- Cuschieri A. Approach to the treatment of acute cholecystitis: open surgical, laparoscopic or endoscopic? Endoscopy 1993; 25(6): 397-398

6- Pham T.H. and Hunter J.G. Gallbladder and the Extrahepatic Biliary System.Chapter 32

Pp 1321-1324.Brunicardi F.C,et al.Schwartz's Principles of Surgery.Tenth edition.2015.

7-Williams N.S .Bulstrode C.J.K. O'Connell P.R. Bailey \& Love's Short Practice of Surgery 26th edition The gall bladder and bile ducts. 1108 .

8-Kohji Okamoto et al. Tokyo Guidelines 2018: flowchart for the management of acute cholecystitis. J Hepatobiliary Pancreat Sci (2018) 25:55-72.

9- Kerwat D.,Zargaran A. Bharamgoudar R., Arif N., Bello G.Sharma B. Kerwat R. Early laparoscopic cholecystectomy is more cost-effective than delayed laparoscopic cholecystectomy in the treatment of acute cholecystitis. ClinicoEconomics and Outcomes Research 2018:10 119-125.

10- Acar T,\&, Kamer E, Acar N, Atahan K, Bağ H, Haciyanlı M, Akgül Ö. Laparoscopic cholecystectomy in the treatment of acute cholecystitis :comparison of results between early and late cholecystectomy. Pan African Medical Journal. 2017; 26:49.

11- Zafar S.N, Obirieze A, Adesibikan B,et al .Optimal Time for Early Laparoscopic Cholecystectomy for Acute Cholecystitis. JAMA Surg. 2015;150(2):129-136.

12- Gul R., Dar R.A.,Sheikh R.A, Salroo N.A, Matoo A.R, and WaniS.H. Comparison of Early and Delayed Laparoscopic Cholecystectomy for Acute Cholecystitis: Experience from A Single Center. N Am J Med Sci. 2013 Jul; 5(7): 414-418.

13- O” zkarde A.B, Tokac M., DumluE.G, Bozkurt B, Çiftçi A.B, , Yetişir F, Kılıç M. Early Versus Delayed Laparoscopic Cholecystectomy for Acute Cholecystitis: A Prospective, Randomized Study. Int Surg. 2014 Jan-Feb; 99(1): 56-61.

14- Condilis N, Sikalias N, Mountzalia L, Vasilopoulos J, Koynnos C, Kotsifas T. Acute cholecystitis: when is the best time for laparoscopic cholecystectomy? Ann Ital Chir. 2008 Jan-Feb;79(1):23-7.

15- Ratan E.H,Alam H. Early Laparoscopic Cholecystectomy in acute cholecystitis and its sequlae: Experience in tertiary care hospital. Bangladesh Crit Care J September 2017; 5 (2): 101-105.)

16- Kolla SB, Aggarwal S, Kumar A, Kumar R, Chumber S, Parshad R, et al. Early versus delayed laparoscopic cholecystectomy for acute cholecystitis: a prospective randomized trial. Surg Endosc. 2004;18(9):1323-1327. [PubMed]

17-Damani AA, Haider S, Bilal H, Perveen S. Comparison of Operative Time and Length of Hospital Stay in Laparoscopic Cholecystectomy in Acute Versus Chronic Cholecystitis. J Ayub Med Coll Abbottabad. 2015 Jan-Mar;27(1):102-4.

18- Siddiqui T, MacDonald A, Chong PS, Jenkins JT. Early versus delayed laparoscopic cholecystectomy for acute cholecystitis: a meta-analysis of randomized clinical trials.

Am J Surg. 2008 Jan;195(1):40-7.

19- Chang TC, Lin MT, Wu MH, Wang MY, Lee PH. Evaluation of early versus delayed laparoscopic cholecystectomy in the treatment of acute cholecystitis. Hepatogastroenterology. 2009 Jan-Feb;56(89): 26-8.

20-Ohta M, Iwashita Y, Yada K, Ogawa T, Kai S, Ishio T, Shibata K, Matsumoto T, Bandoh T, Kitano S. Operative timing of laparoscopic cholecystectomy for acute cholecystitis in a Japanese institute. JSLS. 2012 Jan-Mar;16(1):65-70.

21- Skouras C. Jarral O. Deshpande R. Zografos G. Habib N. Zacharakis E. Is early laparoscopic cholecystectomy for acute cholecystitis preferable to delayed surgery?: Best evidence topic (BET). International Journal of Surgery. Volume 10, Issue 5, 2012, Pages 250-258.

22- Falor AE, de Virgilio C, Stabile BE, Kaji AH, Caton A,Kokubun BA, et al. Early laparoscopic cholecystectomy for mild gallstone pancreatitis: time for a paradigm shift. Arch Surg 2012;147(11):10311035 .

23 Lo C. M, Liu C. L, Fan S.T, Lai E.C, and Wong J. Prospective randomized study of early versus delayed laparoscopic cholecystectomy for acute cholecystitis. Annals of Surgery 1998 Apr;227(4):461-7.

24- Al-Qahtani H.H. Laparoscopic cholecystectomy within one week from the onset of acute cholecystitis: A 6-year experience. Journal of Taibah University Medical Sciences (2013) 8(1), 38-43.

25- Al-Mulhim A.A. Timing of Early Laparoscopic Cholecystectomy for Acute Cholecystitis. Journal of the Society of Laparoscopic Surgeons 2008 Jul-Sep; 12(3): 282-287.

26- Prakash K, Jacob G. ,Lekha V, Venugopal A, Venugopal B, Ramesh H. Laparoscopic cholecystectomy in acute cholecystitis.Surg Endosc 2002;16:180-3.(Pubmed) 